\begin{tabular}{|l|l|l||}
\hline \multicolumn{2}{|c|}{ PublisherInfo } \\
\hline \hline PublisherName & $:$ & BioMed Central \\
\hline \hline PublisherLocation & $:$ & London \\
\hline \hline PublisherImprintName & $:$ & BioMed Central \\
\hline \hline
\end{tabular}

\title{
Roving sharks
}

\begin{tabular}{|l|l|l||}
\hline \multicolumn{2}{|c|}{ ArticleInfo } \\
\hline \hline ArticleID & $:$ & 4150 \\
\hline \hline ArticleDOI & $:$ & $10.1186 /$ gb-spotlight-20010716-02 \\
\hline \hline ArticleCitationID & $:$ & spotlight-20010716-02 \\
\hline \hline ArticleSequenceNumber & $:$ & 221 \\
\hline \hline ArticleCategory & $:$ & Research news \\
\hline ArticleFirstPage & $:$ & 1 \\
\hline \hline ArticleLastPage & $:$ & 2 \\
\hline \hline & & RegistrationDate : 2001-07-16 \\
ArticleHistory & $:$ & OnlineDate \\
\hline \hline ArticleCopyright & $:$ & BioMed Central Ltd2001-16 \\
\hline \hline ArticleGrants & $:$ & \\
\hline \hline ArticleContext & $:$ & 130592211 \\
\hline \hline
\end{tabular}




\section{Jonathan B Weitzman}

Email: jonathanweitzman@hotmail.com

In a Brief Communication in the July 12 Nature, Pardini et al. report the use of genetic analysis to track the movements of great white sharks, Carcharodon carcharias (Nature 2001, 412:139-140). Analysis of DNA sequences from the maternally inherited mitochondrial genome provided evidence for long-term isolation of female sharks in three distinct populations (off the coasts of South Africa, Australia and New Zealand). In contrast, they found no sequence differentiation for microsatellite loci in the nuclear genome, implying extensive male-mediated gene flow. The authors conclude that female sharks are philopatric (non-roving), while males make large trans-oceanic excursions. Thus sex-biased dispersal may occur in fish, and is not, as previously thought, limited to birds and mammals.

\section{References}

1. Nature, [http://www.nature.com]

2. The great white shark, [http://www.ucmp.berkeley.edu/vertebrates/Doug/shark.html] 